\title{
Human Rho(D) Immune Globulin
}

National Cancer Institute

\section{Source}

National Cancer Institute. Human Rho(D) Immune Globulin. NCI Thesaurus. Code C80832.

An immunoglobulin blood product given to the pregnant mother that helps to prevent the Rh negative mother from developing an antibody response to the Rh positive blood cells of the fetus. 